\title{
Elastin peptides regulate HT-1080 fibrosarcoma cell migration and invasion through an Hsp90-dependent mechanism
}

\author{
M Donet ${ }^{1,2}$, S Brassart-Pasco ${ }^{1,2}$, S Salesse ${ }^{1,2}$, F-X Maquart ${ }^{1,2,3}$ and B Brassart ${ }^{\star, 1,2}$ \\ ${ }^{1}$ Laboratoire de Biochimie Médicale et Biologie Moléculaire, UMR CNRS/URCA 7369 MEDyC, UFR Médecine, Université de Reims \\ Champagne Ardenne, 51 Rue Cognacq Jay, 51095 Reims, France; ${ }^{2}$ CNRS UMR 7369, Matrice Extracellulaire et Dynamique \\ Cellulaire - MEDyC, 51 Rue Cognacq Jay, 51095 Reims, France and ${ }^{3} \mathrm{CHU}$ de Reims, Laboratoire Central de Biochimie, 51092 \\ Reims, France
}

Background: The elastin-derived peptides (EDPs) exert protumoural activities by potentiating the secretion of matrix metalloproteinases (MMP) and the plasminogen-plasmin activating system. In the present paper, we studied heat-shock protein 90 (Hsp90) involvement in this mechanism.

Methods: HT-1080 fibrosarcoma cell migration and invasion were studied in artificial wound assay and modified Boyden chamber assay, respectively. Heat-shock protein 90 was studied by western blot and immunofluorescence. Matrix metalloproteinase-2 and urokinase plasminogen activator (UPA) were studied by gelatin \pm plasminogen zymography and immunofluorescence. Heat-shock protein 90 partners were studied by immunoprecipitation. Messenger RNA expression was studied using real-time PCR. Small interfering RNAs were used to confirm the essential role of Hsp90.

Results: We showed that kappa-elastin and VGVAPG elastin hexapeptide stimulated Hsp90, pro-MMP-2 and uPA secretion within $6 \mathrm{~h}$, whereas AGVPGLGVG and GRKRK peptides had no effect. No increase of mRNA level was observed. Heat-shock protein 90-specific inhibitors inhibit EDP-stimulated HT-1080 cell-invasive capacity and restrained EDP-stimulated pro-MMP-2 and uPA secretions. The inhibitory effect was reproduced by using Hsp90-blocking antibody or Hsp90 knockdown by siRNA. Heat-shock protein 90 interacted with and stabilised uPA and pro-MMP-2 in conditioned culture media of HT-1080 fibrosarcoma cells.

Conclusions: Taken together, our results demonstrate that EDPs exert protumoural activities through an Hsp90-dependent mechanism involving pro-MMP-2 and uPA.

Tumour invasion involves many interactions between tumour cells and extracellular matrix (ECM). It is mediated through specific events including receptor-mediated recognition, attachment and ECM degradation, leading to the migration of cells towards a chemotactic agent (Starkey, 1990).

Elastin has a key role in matrix biology. It is the major component of elastic fibres, particularly abundant in tissues such as arteries and lung, and also present in skin, breast, cartilage and some ligaments. It is a long-lived macromolecule with no detectable turnover (Rucker and Dubick, 1984). Its proteolysis by elastase-type proteinases (metallo, serine and cysteine families) is linked to the genesis of several diseases affecting elastin-rich organs (Werb et al, 1982; Visse and Nagase, 2003). This degradation is known to unmask cryptic sites within the ECM and to release matrikines, termed elastin-derived peptides (EDPs or elastokines). These EDPs display a wide range of biological activities, influencing cell migration (Senior et al, 1980; Hinek et al, 1992), differentiation (Grant et al, 1989), proliferation, chemotaxis (Kamoun et al, 1995; Maeda et al, 2007), survival, tumour progression (Timar et al, 1991; Huet et al, 2002; Ntayi et al, 2004), angiogenesis (Robinet et al, 2005), aneurysm formation and atherogenesis (Robert, 1996; Nackman et al, 1997; Hance et al, 2002).

*Correspondence: Dr B Brassart; E-mail: bertrand.brassart@univ-reims.fr

Received 12 March 2014; revised 4 April 2014; accepted 10 April 2014; published online 29 May 2014

(C) 2014 Cancer Research UK. All rights reserved 0007 - 0920/14 
With regard to tumour invasion, soluble peptides obtained from alkaline ( $\kappa$-elastin) or elastase hydrolysis of insoluble elastin, as well as tropoelastin, were shown to increase MMP-1, MMP-2 and MMP-3 production by human skin fibroblasts (Brassart et al, 2001; Huet et al, 2001). Similarly, EDPs stimulated MMP-2, MT1-MMP and TIMP-2 secretion in human HT-1080 fibrosarcoma cell line and, as a consequence, could promote the invasive and metastatic properties of tumour cells (Brassart et al, 1998; Huet et al, 2002). Cell responses to EDPs were attributed to the binding of a VGVAPG hexapeptide sequence, repeated several times in tropoelastin, to elastin receptors with lectin-like properties, named the elastin receptor complex (S-Gal/neuraminidase/ cathepsin A protective protein) or galectin-3. Nevertheless, two other elastin receptors have recently been described (Maeda et al, 2007; Bax et al, 2009). The first one, unaffected by lactose and heparin sulphate, was identified as integrin $\alpha \mathrm{V} \beta 3$. It is involved in the divalent cation-dependent adhesion of human dermal fibroblast to the C-terminal GRKRK motif of tropoelastin. The second one, a lactose-insensitive receptor unknown to date, binds elastin-derived nonapeptides (AGVPGLGVG and AGVPGFGAG) and modulates macrophage migration (Maeda et al, 2007) and lung cancer cells MMP-2 and urokinase plasminogen activator (uPA) secretion (Toupance et al, 2012).

As shown in our previous studies, EDPs increase the secretion of MMP-2 and UPA by HT-1080 cells and induce or potentiate MMP activation cascades in the presence of plasminogen (Huet et al, 2002). Accumulating evidences indicate that Hsp90 has important roles in both physiological and pathological processes, especially in tumour progression (Tsutsumi and Neckers, 2007). Heat-shock protein 90 is a highly conserved and abundant protein, constituting about $1 \%$ of the total intracellular protein (Grenert et al, 1999). In the cytosol, two isoforms of Hsp90 are referred to as Hsp90 $\alpha$ and Hsp90 $\beta$ (Chen et al, 2005). Intriguingly, the Hsp90 $\alpha$ isoform also exists extracellularly (Tsutsumi and Neckers, 2007). Heat-shock protein 90 is secreted by neuron cells, dermal fibroblasts, keratinocytes, macrophages and epithelial cells. It participates in neuronal cell migration, wound healing and viral and bacteria infection. Heat-shock protein $90 \alpha$ can be detected in the blood of cancer patients, and the level of Hsp90 $\alpha$ is positively associated with tumour malignancy (Wang et al, 2009). Eustace et al (2004) reported that extracellular Hsp90 $\alpha$ can interact with MMP-2 and that immobilised geldanamycin, an impermeable inhibitor of $\mathrm{Hsp} 90 \alpha$, inhibits MMP-2 proteolytic activity. More recently, Song et al (2010) and Sims et al (2011) demonstrated that extracellular Hsp90 modulates the MMP-2-dependent tumour processes by enhancing MMP-2 activation, stabilising and preventing MMP-2 inactivation processing.

In the present study, our aim was to determine if EDPs were also able to increase the extracellular presence of Hsp90 and to induce MMP-2 and uPA accumulation in the cell culture medium through the formation of an extracellular Hsp90/MMP-2/uPA complex. We demonstrate that the presence of kappa-elastin (Kel) and VGVAPG stimulates Hsp90 secretion. Heat-shock protein 90 upregulation followed by EDP treatment generated MMP-2 and $\mathrm{uPA}$ accumulation, thereby strongly potentiating cancer cell migration and matrix invasion capacities.

\section{MATERIALS AND METHODS}

Reagents. Synthetic elastin peptides (VGVAPG, AGVPGLGVG and GRKRK) were purchased from Proteogenix (Schiltigheim, France). Matrigel was obtained from Becton-Dickinson (Le Pont de Claix, France). Plasminogen, mouse anti-MMP-2 and anti-uPA antibodies were obtained from Calbiochem (distributed by VWR, Strasbourg, France). Geldanamycin was obtained from Invivogen (Toulouse, France). Radicicol was purchased from Tebu-bio
(Le Perray-en-Yvelines, France). Rabbit monoclonal anti-Hsp90 was from Ozyme (Saint Quentin Yvelines, France). Mouse antiHsp90 was purchased from Abcam (Paris, France). Goat anti-actin was from Santa Cruz (Heidelberg, Germany). Recombinant Hsp $90 \alpha$ protein was from Enzo Life Sciences (Villeurbanne, France).

Materials. Insoluble elastin was prepared from bovine ligamentum nuchae by hot alkali treatment and its purity was assessed by amino-acid analysis and lack of hexoses and hexosamines in the preparation (Jacob and Hornebeck, 1985). Soluble Kel peptides were obtained from purified insoluble elastin by organoalkaline hydrolysis (Samouillan et al, 2001). Peptides with an average molecular weight of $75 \mathrm{kDa}$ were isolated by gel permeation on Sephadex G100 (Sigma-Aldrich, Saint Quentin Fallavier, France).

Cell culture. Human fibrosarcoma cells (HT-1080) and breast carcinoma cells (MDA-MB-231) were obtained from the American Type Culture Collection (Rockville, MD, USA). They were cultured in Dulbecco's modified Eagle's medium (DMEM; Gibco-BRL, Fisher Scientific, Illkirch, France) supplemented with $10 \%$ fetal calf serum.

Preparation of conditioned media. Cells were grown to subconfluency in 24-well culture plates (Nunc, represented in France by Polylabo, Strasbourg) in 10\% serum-containing medium. After $16 \mathrm{~h}$ in serum-free medium, soluble substrates, that is, Kel (from 1 to $100 \mu \mathrm{g} \mathrm{ml}^{-1}$ ) or elastin synthetic peptides $\left(200 \mu \mathrm{g} \mathrm{ml}^{-1}\right)$, were added to serum-free culture medium, and HT-1080 cells were incubated for $6-48 \mathrm{~h}$, in the presence or absence of $1.5 \mu \mathrm{M}$ geldanamycin, $10 \mu \mathrm{m}$ radicicol, $0.1-10 \mu \mathrm{g} \mathrm{ml}^{-1}$ mouse anti-Hsp90 antibody and $1-50 \mu \mathrm{g} \mathrm{ml}^{-1}$ recombinant Hsp90 $\alpha$. Conditioned media were harvested and centrifuged at $10000 \mathrm{~g}$ for $10 \mathrm{~min}$ at room temperature to remove cellular debris. They were used for the determination of Hsp90, MMP-2 and uPA secretion.

Gelatin zymography. Conditioned media from HT-1080 cell cultures were analysed for gelatin degradation by electrophoresis under non-reducing conditions on an SDS-polyacrylamide gel containing $1 \mathrm{mg} \mathrm{ml}^{-1}$ gelatin. The volume of conditioned medium loaded per lane was standardised on the basis of the cell count at harvest. Gels were incubated overnight at room temperature in $50 \mathrm{~mm}$ Tris- $\mathrm{HCl}, 150 \mathrm{~mm} \mathrm{NaCl}$ and $10 \mathrm{~mm} \mathrm{CaCl}_{2}$ (pH 7.4). White lysis zones, indicative of degrading activity, were revealed by staining with Coomassie brilliant blue.

Gelatin plasminogen zymography. For the determination of plasminogen activators, conditioned media were analysed on SDS-polyacrylamide gels containing $1 \mathrm{mg} \mathrm{ml}^{-1}$ gelatin and $3 \mu \mathrm{g} \mathrm{ml}^{-1}$ plasminogen. Following electrophoresis, gels were incubated overnight at room temperature in $100 \mathrm{~mm}$ glycine buffer and EDTA $5 \mathrm{~mm}(\mathrm{pH} 8.3)$. Gelatinolytic activity resulting from plasminogen activation was indicated here by white lysis zones, which were revealed by staining with Coomassie brilliant blue. As a positive control, recombinant urokinase was used; as a negative control, $2 \mathrm{~mm}$ phenylmethylsulphonylfluoride was added to the incubation buffer.

Western blot analysis. Conditioned media were concentrated in Vivaspin from Sartorius stedim (Aubagne, France) and samples were electrophoresed in a $0.1 \%$ SDS and $10 \%$ polyacrylamide gel, under reducing conditions. Proteins were then transferred onto Immobilon-P membrane (Millipore, Saint-Quentin en Yvelines, France). The membrane was blocked with $5 \%$ non-fat dry milk, $0.1 \%$ Tween-20 in a $50 \mathrm{~mm}$ Tris- $\mathrm{HCl}$ buffer and $150 \mathrm{~mm} \mathrm{NaCl}(\mathrm{pH}$ 7.5) (TBS) for $2 \mathrm{~h}$ at room temperature, incubated overnight at $+4{ }^{\circ} \mathrm{C}$ with anti-Hsp90, anti-MMP-2 or anti-uPA antibody and then for $1 \mathrm{~h}$ at room temperature with a second peroxidaseconjugated anti-IgG antibody. Immune complexes were visualised with the ECL Chemoluminescence Detection Kit (GE Healthcare, Orsay, France). 
Hsp90, pro-MMP-2 and uPA detection by immunocytofluorescence. HT-1080 cells were plated on glass slides and incubated in $10 \%$ serum-containing medium. After $16 \mathrm{~h}$ in serum-containing medium, $50 \mu \mathrm{g} \mathrm{ml}^{-1} \mathrm{Kel}$ were added to serum-free culture medium, and HT-1080 cells were incubated for $30 \mathrm{~min}$. They were fixed for $5 \mathrm{~min}$ with $4 \%$ paraformaldehyde. The slides were washed with PBS-T and saturated in PBS-T with 5\% BSA. Cells were then incubated for $1 \mathrm{~h}$ at room temperature with an anti-HSP90, antiMMP-2 and anti-uPA antibody diluted $1 / 400$ in PBS-T with $1 \%$ BSA. Slides were washed in PBS-T and cells were incubated for 30 min with the Alexa-488- or Alexa-568-conjugated secondary antibodies diluted $1 / 1000$ in TBS-T with $1 \%$ BSA. Cells were then washed with PBS-T. Control preparations were incubated with omission of the first antibody. Immunofluorescence-labelled cell preparations were studied using a Zeiss LSM 710 confocal laser scanning microscope with the $\times 60$ oil-immersion objective (Carl Zeiss Microimaging, Heidelberg, Germany).

Primer design for RT-qPCR. Real-time quantitative polymerase chain reaction (RT-qPCR) primers were designed according to sequences of Hsp90 $\alpha$ transcript-1 (Hsp90AA1-001) and Hsp90 $\alpha$ transcript-2 (Hsp90AA1-002) (NM_001017963), MMP-2 (NM_ 004530), uPA (NM_001145031) and EEFa1 (NM_001402). The forward primer for Hsp90 $\alpha$ transcript-1 was $5^{\prime}$-GCCTTCAGA CAGAGCCAAGGT- $3^{\prime}$ and the reverse primer was $5^{\prime}$-TCTTG GGTCTGGGTTTCCTCA-3' with a $101 \mathrm{bp}$ product. The forward
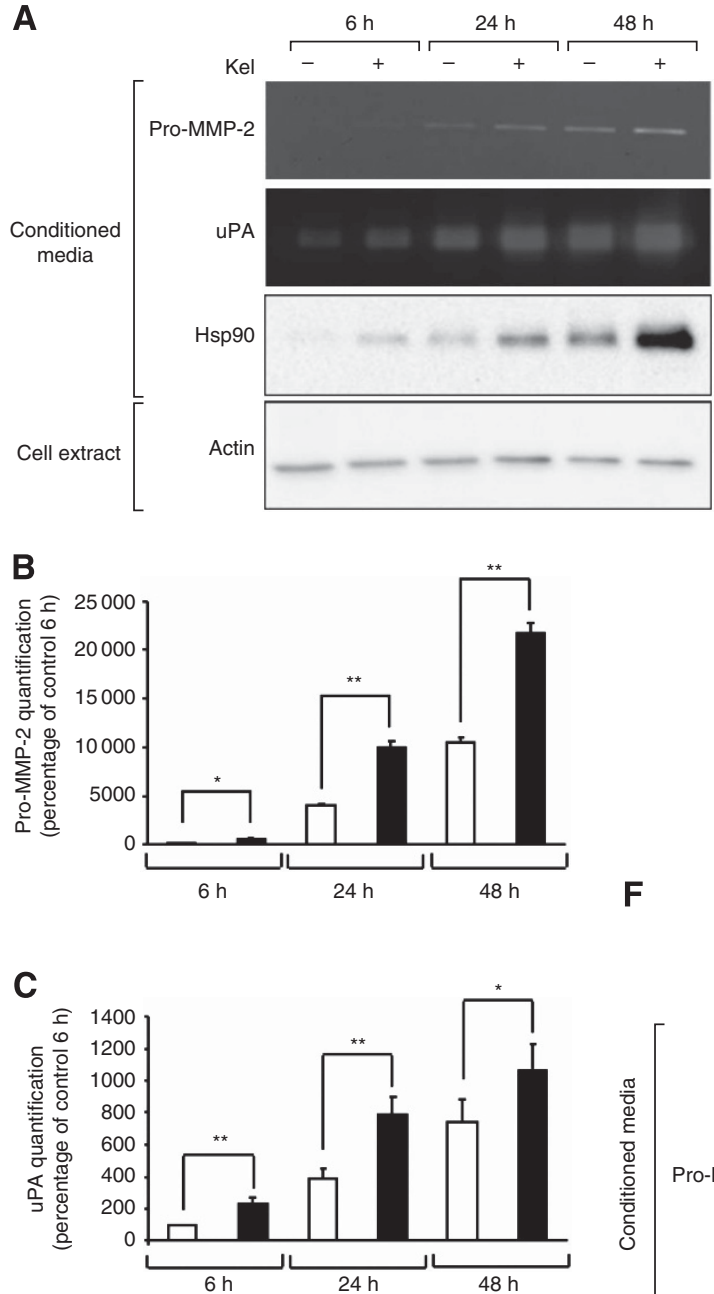

\section{$\mathbf{F}$}

D

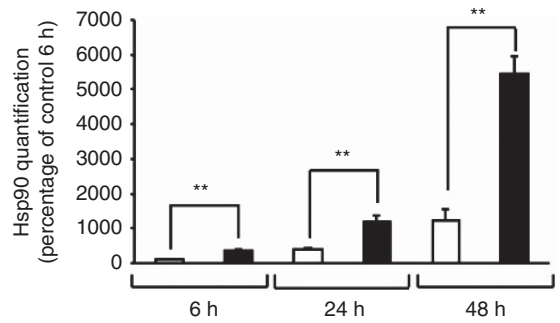

E

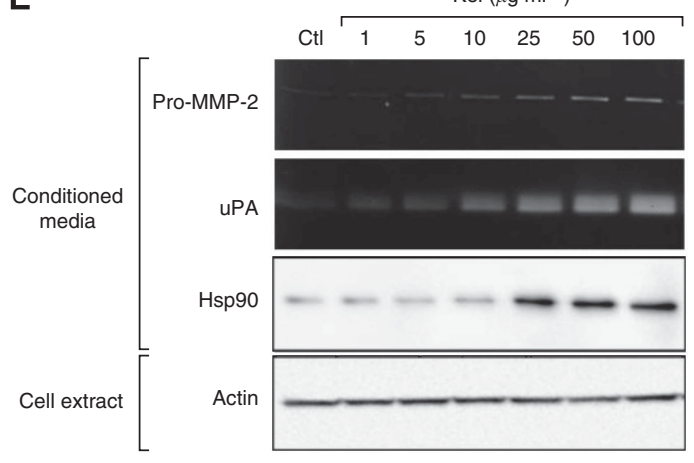

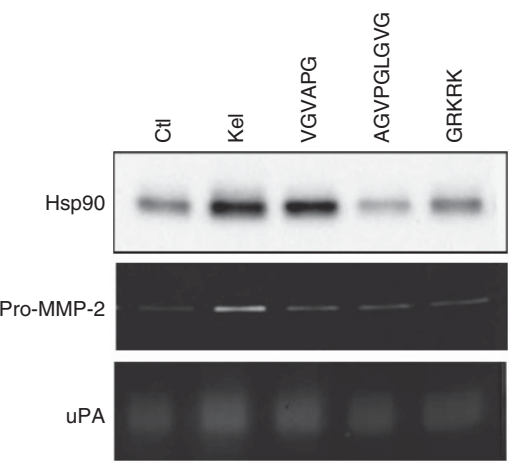

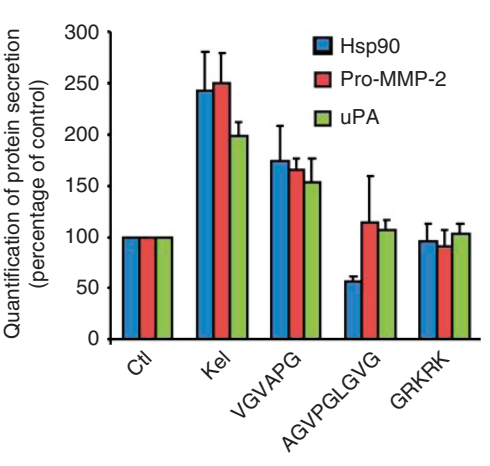

Figure 1. EDPs influence on Hsp90, pro-MMP-2 and uPA secretion. (A) Gelatin zymography, gelatin plasminogen zymography and western blotting analysis of conditioned media and actin content in total cell extracts from HT-1080 cells cultured for 6, 24 and $48 \mathrm{~h}$ in the absence ( - ) or presence of $50 \mu \mathrm{g} \mathrm{ml}^{-1} \mathrm{Kel}(+)$ as described in Materials and Methods section. (B) Quantitative evaluation of pro-MMP-2 secretion by HT-1080 cells on gelatin zymography. Results (mean \pm s.e.m.) were expressed as the percentage of control $6 \mathrm{~h}$ (EDP-untreated cells). ${ }^{\star} P<0.005,{ }^{\star \star *} P<0.001$, significantly different from control. Lighter bars, untreated cells; black bars, EDP-treated cells. (C) Quantitative evaluation of uPA secretion by HT1080 cells on gelatin plasminogen zymography. Results (mean \pm s.e.m.) were expressed as the percentage of control for $6 \mathrm{~h}$ (EDP-untreated cells). ${ }^{\star} P<0.005,{ }^{\star \star} P<0.001$, significantly different from control. Lighter bars, untreated cells; black bars, EDP-treated cells. (D) Quantitative evaluation of Hsp90 secretion by HT-1080 cells by western blotting. Results (mean \pm s.e.m.) were expressed as the percentage of control for $6 \mathrm{~h}$ (EDPuntreated cells). ${ }^{\star \star} P<0.001$, significantly different from control. Lighter bars, untreated cells; black bars, EDP-treated cells. (E) Dose-effect study of EDP treatment (Kel 0-100 $\mathrm{g} \mathrm{ml}^{-1}$ ) on pro-MMP-2, uPA and Hsp90 secretion. Gelatin zymography, gelatin plasminogen zymography and western blotting analysis of conditioned media and actin content in cell extracts from HT-1080 cells cultured for $24 \mathrm{~h}$ in the absence (Ctl) or in the presence of 1-100 $\mathrm{g} \mathrm{ml}^{-1} \mathrm{Kel}$. (F) Gelatin zymography, gelatin plasminogen zymography and western blotting analysis of conditioned media from HT-1080 cells cultured for $24 \mathrm{~h}$ in the absence (Ctl) or in the presence of $50 \mu \mathrm{g} \mathrm{ml}^{-1} \mathrm{Kel}$ (Kel) or synthetic elastin peptides (VGVAPG, AGVPGLGVG, GRKRK). All synthetic peptides were used at $200 \mu \mathrm{g} \mathrm{ml}^{-1}$. Quantitative evaluation of protein secretions by HT-1080 cells on gelatin zymography, gelatin plasminogen zymography and by western blotting. Results (mean \pm s.e.m.) were expressed as the percentage of control (EDP-untreated cells). 
primer for $\mathrm{Hsp} 90 \alpha$ transcript-2 was 5'-CGTCAGTTGCTTCA GCGTCC- $3^{\prime}$ and the reverse primer was $5^{\prime}$-TCAACTGGGCA ATTTCTGCCT- $3^{\prime}$ with a $151 \mathrm{bp}$ product. The forward primer for MMP-2 was $5^{\prime}$-TCTTCCCCTTCACTTTCCTG- $3^{\prime}$ and the reverse primer was $5^{\prime}$-ACTTGCGGTCGTCATCGTA- $3^{\prime}$ with a $111 \mathrm{bp}$ product. The forward primer for uPA was $5^{\prime}$-CCCAGTTTGGCAC AAGCTGT- $3^{\prime}$ and the reverse primer was $5^{\prime}$-CCCTGGCAGG AATCTGTTTTC- $3^{\prime}$ with a $202 \mathrm{bp}$ product. The forward primer for EEF1al was $5^{\prime}$-CTGGAGCCAAGTGCTAACATGCC- $3^{\prime}$ and the reverse primer was $5^{\prime}$-CCGGGTTTGAGAACACCAGTC- ${ }^{\prime}$ with a 221 bp product. All primers were synthesised by Eurogentec (Maine Et Loire, France).

RT-qPCR. Total RNA isolation was performed using the Qiagen RNeasy Kit (Qiagen, Courtaboeuf, France) according to the manufacturer's instructions. Complementary DNA was prepared from $200 \mathrm{ng}$ of total RNA by reverse transcription (RT) using a Maxima First Strand cDNA Synthesis Kit (Thermo Fisher Scientific, Villebon-sur-Yvette, France) according to the manufacturer's protocol. Real-time PCR was performed using a Maxima SYBR GREEN/ROX qPCR Master Mix (Thermo Fisher Scientific) on the Stratagene Mx3005P qPCR detection system (Agilent Technologies, Les Ulis, France). Polymerase chain reaction conditions were $15 \mathrm{~min}$ at $+95^{\circ} \mathrm{C}$, followed by 40 cycles each consisting of $15 \mathrm{~s}$ at $+95^{\circ} \mathrm{C}$ (denaturation) and $30 \mathrm{~s}$ at $+60{ }^{\circ} \mathrm{C}$ (annealing/extension). Polymerase chain reaction efficiency of the primer sets (Hsp90 $\alpha$ transcript-1, Hsp90 $\alpha$ transcript-2, MMP-2, uPA and EEF1a1) was controlled via the slope of a standard curve. Results were standardised to the EEFlal gene expression level. Relative gene expression was determined with the formula fold induction $=2-\Delta \Delta \mathrm{Ct}$, where $\Delta \Delta \mathrm{Ct}=(\mathrm{Ct}$ GI (unknown sample)-Ct GI (reference sample))-(Ct GR (unknown sample) - Ct GR (reference sample)). GI represents the Gene of Interest and GR the Reference Gene. The entire experiment from RNA extraction to real-time PCR steps was repeated four times with different sets of samples.

siRNA transfection. Small interfering RNA specific to human Hsp90 $\alpha$ (FlexiTube GeneSolution GS3320 for HSP90AA1) and negative control siRNA (non-targeting pool), which do not target any genes, were purchased from Qiagen. The siRNA target different regions of the Hsp $90 \alpha$ mRNA: 1st siRNA target sequence ( $5^{\prime}$-AACCCTGACCATTCCATTATT- $\left.{ }^{\prime}\right)$, 2nd siRNA target sequence (5'-TGCACTGTAAGACGTATGTAA-3 $\left.{ }^{\prime}\right)$, 3rd siRNA target sequence $\left(5^{\prime}\right.$-CAGAATGAAGGAGAACCAGAA- $\left.3^{\prime}\right)$ and 4 th siRNA target sequence ( $5^{\prime}$-ATGGCATGACAACTACTTTAA- $\left.3^{\prime}\right)$.
A

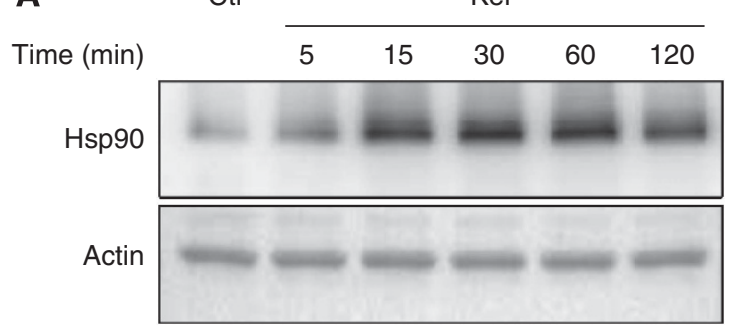

B

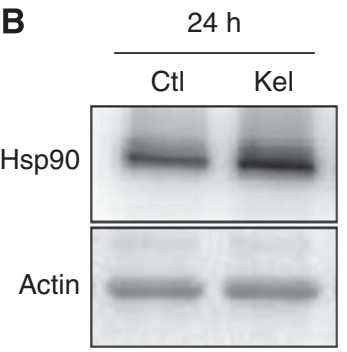

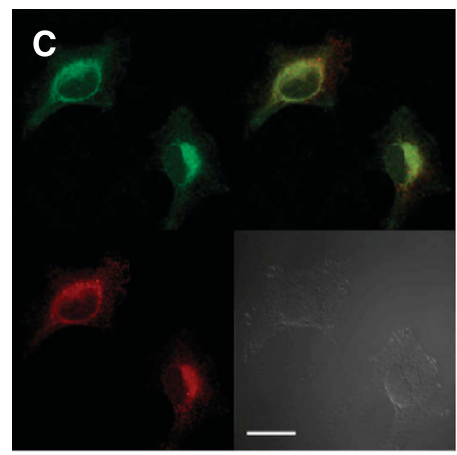
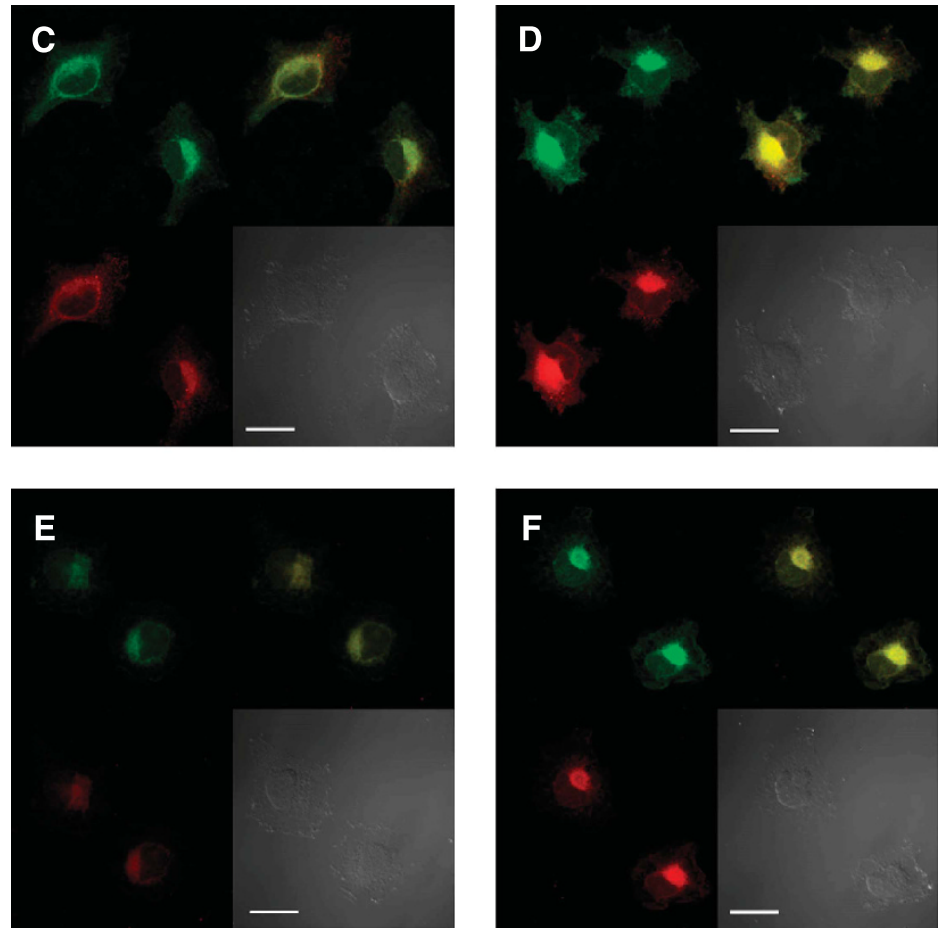

Figure 2. Evaluation of the intracellular Hsp90, MMP-2 and uPA expression in HT-1080 cells. (A) Western blotting analysis of intracellular Hsp90 using a rabbit anti-Hsp90 monoclonal antibody and probing with anti-actin antibody were carried out as described in Materials and Methods section. (B) Western blotting analysis of intracellular $\mathrm{Hsp} 90$ at $24 \mathrm{~h}$ using a rabbit anti-Hsp90 monoclonal antibody and probing with anti-actin. (C-F) Localisation of Hsp90, pro-MMP-2 and uPA in HT-1080 cells in the presence (D, F) (Kel $50 \mu \mathrm{g} \mathrm{ml}^{-1}$ ) or absence (C, E) (control) of EDPs. Cells were cultured on glass slides, fixed with paraformaldehyde and labelled with an anti-Hsp90 (green), anti-pro-MMP-2 form (red) (C, D), anti-uPA (red) (E, F). Yellow staining corresponds to areas where Hsp90, pro-MMP-2 or uPA colocalised. Scale bar: $10 \mu \mathrm{m}$. 
Exponentially growing HT-1080 cells were transfected with two siRNA pools (SiRNA1: 1st and 2nd siRNA target sequences/ siRNA2: 3rd and 4th siRNA target sequences) (20 nM) (Qiagen) using Lipofectamine 2000 (Life Technologies, Fisher Scientific). Decrease of Hsp $90 \alpha$ mRNA expression was assessed by RT-qPCR at $48 \mathrm{~h}$ after transfection. Decrease of Hsp90 protein expression was monitored by western blotting and immunocytofluorescence $72 \mathrm{~h}$ after siRNA transfection. Cells were subjected to EDP treatment for pro-MMP-2 and UPA secretion $48 \mathrm{~h}$ after transfection.

Artificial wound assay. HT-1080 cells were seeded on uncoated 12 -well plates in $10 \%$ serum-containing medium. A homogeneous wound was created in each well by scraping cells with a tip followed by two washes with DMEM to eliminate dead cells and cellular debris. Soluble substrates, that is, $\operatorname{Kel}\left(50 \mu \mathrm{g} \mathrm{ml}^{-1}\right)$, were added to serum-free culture medium and HT-1080 cells were incubated for $24 \mathrm{~h}$, in the presence or absence of $1.5 \mu \mathrm{M}$ geldanamycin or $10 \mu \mathrm{m}$ radicicol. Wound closure was evaluated by videomicroscopy (Axiovert $200 \mathrm{M}$; Zeiss).

In vitro invasion assay. Invasion was assessed in modified Boyden chambers (tissue culture-treated, $6.5-\mathrm{mm}$ diameter, $8-\mu \mathrm{m}$ pore, Transwell; Dutscher, Brumath, France) as described previously (Huet et al, 2002). Briefly, DMEM supplemented with 10\% fetal bovine serum and 2\% BSA was used as a chemoattractant. In total, $5 \times 10^{4}$ cells were suspended in serum-free DMEM containing $0.2 \%$ BSA and seeded onto membranes coated with Matrigel $\left(50 \mu \mathrm{g} \mathrm{cm}^{-2}\right)$. After a $6 \mathrm{~h}$ incubation period, cells were fixed with methanol and stained with crystal violet for $15 \mathrm{~min}$. Cells remaining on the upper face of the membranes were scraped, and those on the lower face were counted using an inverted microscope. Experiments were reproduced three times in triplicates. Differences in cell invasiveness were evaluated by Student's $t$-test.

Statistical analysis. Each experiment was performed at least three times from separate sets of culture and data were expressed as mean \pm s.e.m. Comparisons were performed using Student's $t$-test.

\section{RESULTS}

Influence of EDPs on Hsp90, pro-MMP-2 and uPA secretion by HT-1080. We previously demonstrated that EDPs upregulate invasiveness of tumour cells via the release of proteolytic enzymes. The mechanism leading to MMP-2- and uPA-increased release is unclear. We have not yet determined if this upregulation results from posttranscriptional mechanisms or increased enzyme stability. Heat-shock protein 90 is required for the activation and stabilisation of a wide variety of client proteins including MMP-2 and $\mathrm{uPA}$, involved in promoting tumour invasiveness. Thus, we decided to study Hsp90 expression by HT-1080 after EDP stimulation. Serum-free culture media supplementation with EDPs (Kel $50 \mu \mathrm{g} \mathrm{ml}^{-1}$ ) for $6-48 \mathrm{~h}$ did not induce HT-1080 cell growth. Those peptides have no cell toxicity as assessed by trypan blue exclusion (data not shown) and did not modify the overall protein content visualised by actin level in total cell extract from 6 to $48 \mathrm{~h}$ of culture (Figure 1A). Elastin-derived peptides stimulated proMMP-2 secretion by 4.5-, 2.5- and 2.1-fold at $6 \mathrm{~h}, 24 \mathrm{~h}$ and $48 \mathrm{~h}$, respectively, as shown by zymography analysis (Figure 1B). Gelatin plasminogen zymography analysis revealed an increase in uPA secretion after EDP treatment by 2.3-, 2.0- and 1.4-fold at $6 \mathrm{~h}, 24 \mathrm{~h}$ and $48 \mathrm{~h}$, respectively (Figure 1C). Heat-shock protein 90 secretion was also increased as soon as $6 \mathrm{~h}$ following supplementation of the
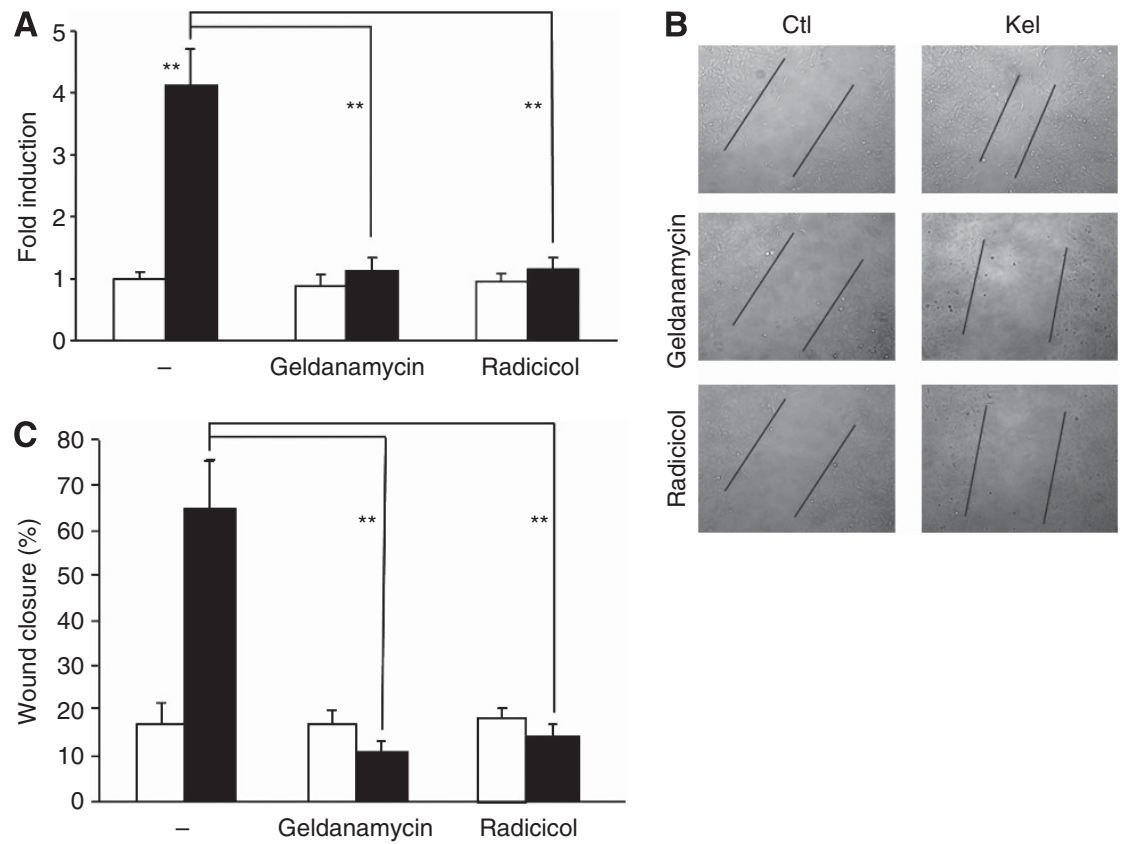

Figure 3. Hsp90 regulates migration and invasion of EDP-treated HT-1080 cells. (A) Geldanamycin and radicicol, two Hsp90 inhibitors, block the Matrigel invasion of EDP-stimulated HT-1080 cells. HT-1080 cells were incubated with $1.5 \mu \mathrm{m}$ geldanamycin or $10 \mu \mathrm{m}$ radicicol during $1 \mathrm{~h}$ before being stimulated or not for $6 \mathrm{~h}$ with $50 \mu \mathrm{g} \mathrm{ml}^{-1} \mathrm{EDPs}$. At the end of the incubation period, cells were fixed with methanol and stained with crystal violet for $15 \mathrm{~min}$. Cells remaining on the upper face of the membranes were scrapped and those on the lower face were counted. Data are expressed as mean \pm S.E.M. values from three independent experiments, each performed in triplicate. ${ }^{\star \star} P<0.001$, significantly different from Kel alone). Lighter bars, untreated cells; black bars, EDP-treated cells. (B) Heat-shock protein 90 inhibitors (geldanamycin and radicicol) inhibit the EDP-stimulated migration of HT-1080 cells. HT-1080 cells have been seeded in 12-well plates and a homogeneous wound was created in each well by scraping cells with a tip. Cells were incubated with $1.5 \mu \mathrm{m}$ geldanamycin or $10 \mu \mathrm{m}$ radicicol during $1 \mathrm{~h}$ before being stimulated or not for $24 \mathrm{~h}$ with $50 \mu \mathrm{g} \mathrm{ml}^{-1}$ EDPs and cell migration was evaluated by microscopy. (C) Quantification of the wound closure. ${ }^{\star \star} P<0.001$, significantly different from Kel alone. 
culture medium with $50 \mu \mathrm{g} \mathrm{ml}^{-1}$ of Kel. The maximum level of Hsp90 production (4.5-fold increase) by HT-1080 cells was found in the presence of $50 \mu \mathrm{g} \mathrm{ml}^{-1}$ of Kel after $48 \mathrm{~h}$ of incubation (Figure 1D). As shown in Figure 1E, zymography and western blotting analysis of EDP-treated HT-1080 cell media indicated that Kel-mediated effect on the pro-MMP-2, uPA and Hsp90 secretion was concentration-dependent; a significant 2.4-fold increase in Hsp90 secretion was observed following supplementation of the culture medium with $25 \mu \mathrm{g} \mathrm{ml}^{-1}$ of Kel and a 3.2-fold maximum increase of Hsp90 secretion by HT-1080 cells was found in the presence of $50 \mu \mathrm{g} \mathrm{ml}^{-1} \mathrm{Kel}$. The increase of Hsp90, MMP-2 and uPA was also observed in the conditioned media of MDA-MB-231 breast carcinoma cells treated with EDP $\left(50 \mu \mathrm{g} \mathrm{ml}^{-1}\right)$ for $24 \mathrm{~h}$ (Supplementary Figure 1).
Next, we examined whether other elastin peptides (VGVAPG, AGVPGLGVG and GRKRK) could also modulate Hsp90 production by HT-1080 cells, parallel to pro-MMP-2 and uPA secretion. While AGVPGLGVG and GRKRK peptides had no impact, HT-1080 cells grown in the presence of $200 \mu \mathrm{g} \mathrm{ml}^{-1}$ VGVAPG for $24 \mathrm{~h}$ secreted significantly more pro-MMP-2 (1.8fold), uPA (1.5-fold) and Hsp90 (1.9-fold) (Figure 1E) compared with control. Thus, EDPs stimulate proteases and Hsp90 secretion in a time- and concentration-dependent manner, and VGVAPG reproduced, at least partly, the EDP stimulation.

EDPs induce Hsp90, pro-MMP-2 and UPA synthesis by a posttranscriptional mechanism. Total RNAs obtained from HT1080 cells cultured at different time points $(0,5,15,30,60,120 \mathrm{~min}$
A

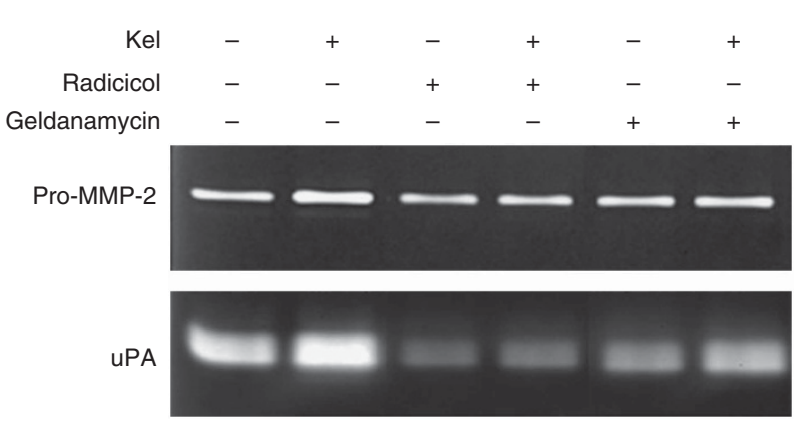

C

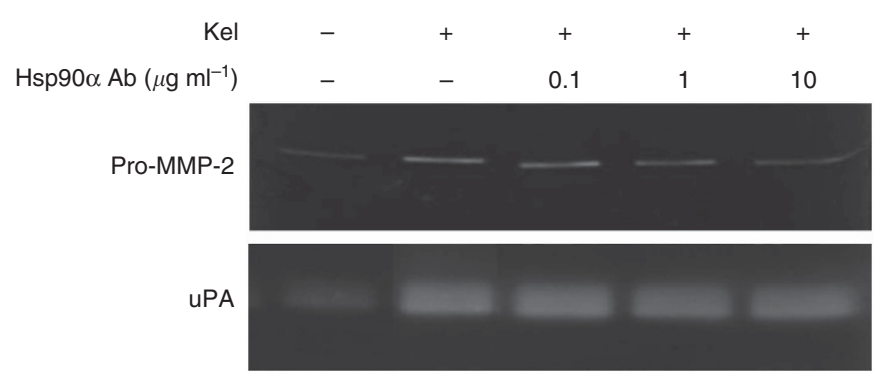

E

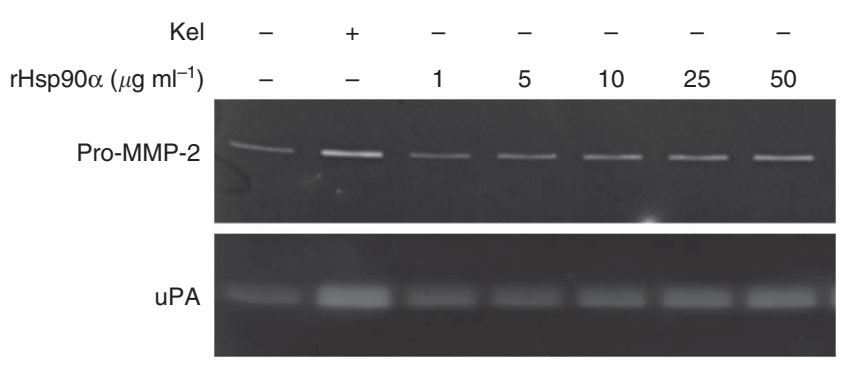

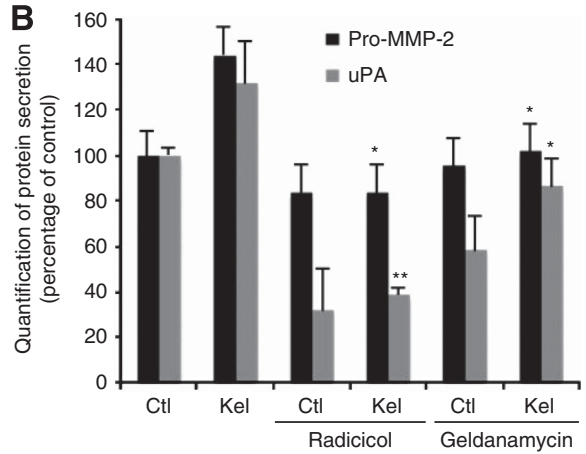
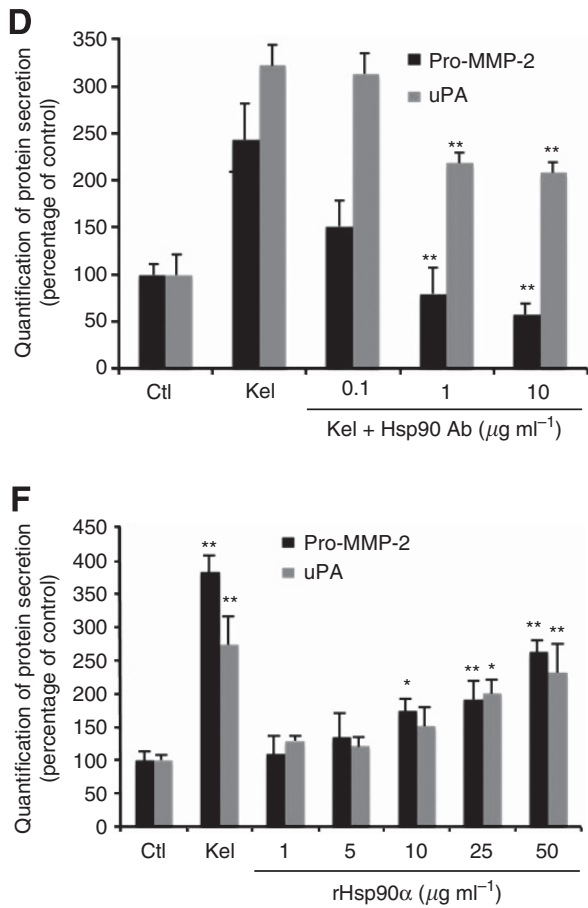

Figure 4. EDP increases extracellular Hsp90 and promotes pro-MMP-2 and uPA accumulation in HT-1080 culture media. (A) Gelatin zymography and gelatin plasminogen zymography analysis of Hsp90 inhibitors effect ( $1.5 \mu \mathrm{M}$ geldanamycin and $10 \mu \mathrm{M}$ radicicol) on the production of pro-MMP2 and uPA in the presence $\left(+: 50 \mu \mathrm{g} \mathrm{ml}^{-1}\right.$ ) or in the absence ( - ) of EDPs (24 h of treatment). (B) Quantitative evaluation of protein secretions by HT-1080 cells on gelatin zymography and gelatin plasminogen zymography. Results (mean \pm s.e.m.) were expressed as the percentage of control (EDP-untreated cells). ${ }^{*} P<0.005,{ }^{*} P<0.001$, significantly different from Kel alone. (C) Gelatin zymography and gelatin plasminogen zymography analysis of monoclonal anti-Hsp90 antibody effect on the production of pro-MMP-2 and uPA in EDP-treated HT-1080 cells (50 $\left.\mu \mathrm{g} \mathrm{ml}^{-1}\right)(24 \mathrm{~h}$ of treatment). (D) Quantitative evaluation of protein secretions by HT-1080 cells on gelatin zymography and gelatin plasminogen zymography. Results (mean \pm s.e.m.) were expressed as the percentage of control (EDP-untreated cells). ${ }^{\star} P<0.005,{ }^{\star \star} P<0.001$, significantly different from Kel alone. (E) Gelatin zymography and gelatin plasminogen zymography analysis of the effect of recombinant Hsp $90 \alpha$ protein on the production of pro-MMP-2 and uPA by HT-1080 cells (24 h of treatment). (F) Quantitative evaluation of protein secretions by HT-1080 cells on gelatin zymography and gelatin plasminogen zymography. Results (mean \pm s.e.m.) were expressed as the percentage of control (EDP-untreated cells). ${ }^{\star} P<0.005$,

$\star \star P<0.001$, significantly different from control. 
and $24 \mathrm{~h})$ in the absence or presence of $\mathrm{Kel}\left(50 \mu \mathrm{g} \mathrm{ml}^{-1}\right)$ were analysed by real-time PCR. Kappa-elastin treatment induced only minor alteration of Hsp90 transcripts 1 and 2, MMP-2 and uPA mRNA levels from 5 to 120 min (Supplementary Figure 2A-C) and no statistical variation at $24 \mathrm{~h}$ either (Supplementary Figure 2D). These results suggest that Hsp90 increased secretion, and proteases release after EDP treatment may not implicate regulation at the transcriptional level. On the contrary, as previously reported for the MMP-2 and UPA expression (Toupance et al, 2012), the presence of EDPs rapidly enhanced Hsp90 protein synthesis; Kel $\left(50 \mu \mathrm{g} \mathrm{ml}^{-1}\right)$ triggered a 4-fold induction of intracellular Hsp90 production after a $15 \mathrm{~min}$ incubation period and a maximal 4.5fold induction after $30 \mathrm{~min}$ (Figure 2A) compared with control. Twenty-four-h Kel treatment maintained a 1.6-fold upregulated intracellular Hsp90 level (Figure 2B). Immunocytofluorescence study of Hsp90, pro-MMP-2 and uPA production by Kel-treated HT-1080 cells confirmed the upregulation of Hsp90, pro-MMP-2 and uPA synthesis (Figure 2C-F). A perinuclear colocalisation was highlighted for Hsp90 and pro-MMP-2, as well as for Hsp90 and uPA. These results demonstrate that EDPs induce Hsp90, proMMP-2 and uPa synthesis by a posttranscriptional mechanism.

Influence of EDP-dependent Hsp90 expression on the migratory and invasive properties of HT-1080 cells. Under our experimental conditions (Huet et al, 2002), untreated HT-1080 cells had a low ability to migrate and penetrate a Matrigel matrix, contrasting with the high capacity of those cells to migrate and invade in the presence of $50 \mu \mathrm{g} \mathrm{ml}^{-1} \mathrm{Kel}$ (Figure $3 \mathrm{~A}-\mathrm{C}$ ). When untreated HT-1080 cells were incubated with either Hsp90 inhibitor geldanamycin $(1.5 \mu \mathrm{M})$ or radicicol $(10 \mu \mathrm{M})$, no change was detected in the migratory and invasive cell capacities $v s$ control cells. Adding Kel $\left(50 \mu \mathrm{g} \mathrm{ml}^{-1}\right)$ after geldanamycin or radicicol preincubation significantly reduced the wound closure by 6.5 - and 4.6-fold, respectively (Figure $3 \mathrm{~B}$ and $\mathrm{C}$ ), and inhibited the cell invasion of Matrigel by 3.7- and 3.6-fold, respectively, as compared with cells treated with $\mathrm{Kel}$ alone (Figure 3A). Taken together, these results demonstrate that Hsp90 regulates EDP-stimulating effect on HT-1080 cells migratory and invasive capacities of HT-1080 cells.

Influence of Hsp90 on pro-MMP-2 and uPA expression by HT-1080 cells. To determine if Hsp90 influences pro-MMP-2 and uPA expression, we performed zymography analysis on cell media pretreated with geldanamycin $(1.5 \mu \mathrm{M})$ or radicicol $(10 \mu \mathrm{M})$ and in the presence or absence of EDPs $\left(50 \mu \mathrm{g} \mathrm{ml}^{-1}\right)$ (Figure 4A). For the cells incubated either with geldanamycin or radicicol alone, pro-MMP-2 expression was unaffected, while uPA expression was reduced. In cells treated with Kel, geldanamycin and radicicol significantly inhibited pro-MMP-2 (1.7- and 1.3-fold, respectively) and uPA synthesis (3.4- and 1.5-fold, respectively). We further investigated whether supplementation of culture media with Hsp90-blocking antibodies $\left(0.1-10 \mu \mathrm{g} \mathrm{ml}^{-1}\right)$ could disrupt the EDP-dependent pro-MMP-2 and UPA expression. We observed that pro-MMP-2 and uPA levels in cell medium decreased with Hsp90 antibody in a concentration-dependent manner (Figure 4B). Although the Hsp90 antibody moderately blocked the uPA production $(-35 \%), 10 \mu \mathrm{g} \mathrm{ml}^{-1}$ of Hsp90 antibody induced a marked decrease of pro-MMP-2 secretion (3.3-fold decrease).

To explore the role of Hsp90 $\alpha$ on pro-MMP-2 and uPA, we evaluated the impact of recombinant Hsp90 $\alpha$ ( $\mathrm{rHsp} 90 \alpha)$ $\left(1-50 \mu \mathrm{g} \mathrm{ml}^{-1}\right)$ on HT-1080 cells. As compared with EDP-treated cells, rHsp90 $\alpha$ effect was concentration-dependent; significant and maximum increase of pro-MMP-2 and uPA was observed following supplementation of culture media with $50 \mu \mathrm{g} \mathrm{ml}^{-1}$ of rHsp90 $\alpha$ (2.0- and 2.9-fold respectively) (Figure 4C). Collectively, these results strongly support the idea that EDPs increase expression and secretion of $\mathrm{Hsp} 90 \alpha$, which, as an extracellular chaperone protein, may protect pro-MMP-2 and uPA from degradation and increase their content in the conditioned media.

Extracellular Hsp90 interacts with MMP-2 and uPA. Our data show that EDPs enhance the expression of Hsp90, pro-MMP-2 and uPA. These three proteins are intracellularly colocalised. By affecting Hsp90 amount in the conditioned media, pro-MMP-2 and uPA were also affected. We thus studied if Hsp90 was able to interact with MMP-2 and uPA in the conditioned medium. After $24 \mathrm{~h}$ incubation with $\mathrm{Kel}\left(50 \mu \mathrm{g} \mathrm{ml}^{-1}\right)$, secreted Hsp90 was immunoprecipitated and Hsp90 client proteins were revealed by western blotting. As shown in Figure 5, we found that extracellular Hsp90 interacts with uPA and pro-MMP-2, and also with the MMP-2 active form. No enzymes were detected in the output, suggesting a complete interaction between those three extracellular proteins.

Hsp90 is essential for EDP-dependent pro-MMP-2 and uPA secretion. To confirm the essential role of Hsp90 in EDPdependent pro-MMP-2 and uPA release, we transfected HT-1080 cells with two pools of Hsp90 siRNA (siRNA1 and siRNA2) or negative control siRNA $(-)$ as described in Materials and Methods section. A strong decrease of Hsp90 mRNA expression $(-88 \%$ and $-86 \%$ for siRNA1 and siRNA2, respectively, compared with control) was observed $48 \mathrm{~h}$ after siRNA cell transfection (Figure 6A). To validate the Hsp90 knockdown, its protein expression pattern was analysed $72 \mathrm{~h}$ after transfection by western blotting. In siRNA1 and siRNA2 cells, $80 \%$ and $77 \%$ inhibition of Hsp90 protein expression was observed vs negative control siRNA (Figure 6B). In contrast, the actin expression was not affected by the Hsp90 siRNA. Heat-shock protein 90 knockdown was confirmed by immunocytofluorescence (Figure 6C). Forty-eight hours after transfection, siRNA-transfected cells were tested for pro-MMP-2 and uPA secretion in the absence or presence of EDPs for $24 \mathrm{~h}$. The Hsp90 knockout by siRNA1 and siRNA2 affected the protease secretion compared with negative control siRNA-transfected cells (pro-MMP-2: -56 and $-52 \%$; uPA: -61 and $-64 \%$, respectively) (Figure 6D). In the presence of $50 \mu \mathrm{g} \mathrm{ml}^{-1} \mathrm{Kel}$, pro-MMP-2 and uPA amount still

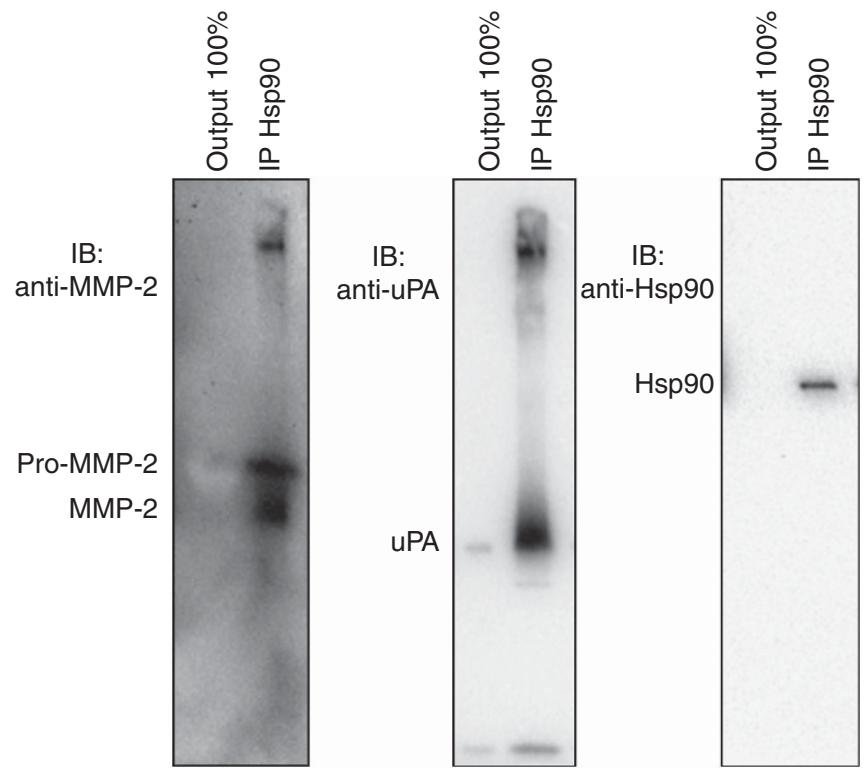

Figure 5. Hsp90 interacts with MMP-2 and uPA. Immunoprecipitation of extracellular Hsp90 from EDP-treated HT-1080 cells' conditioned media and bound MMP-2 and UPA analysis by western blotting. Output 100\% represent the unbound protein after Hsp90 immunoprecipitation. 
A

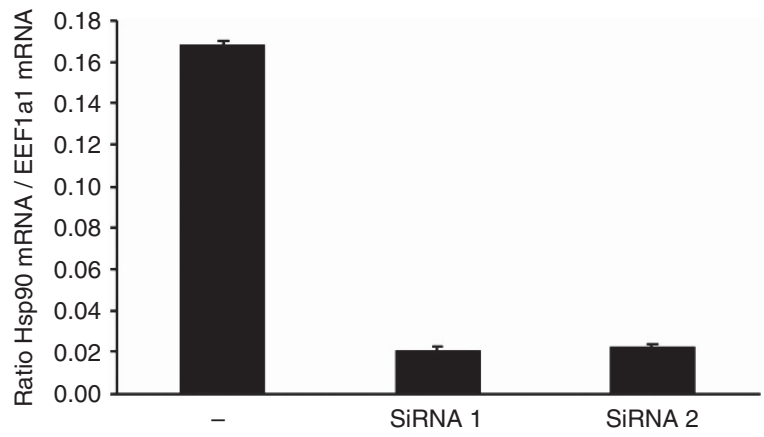

B
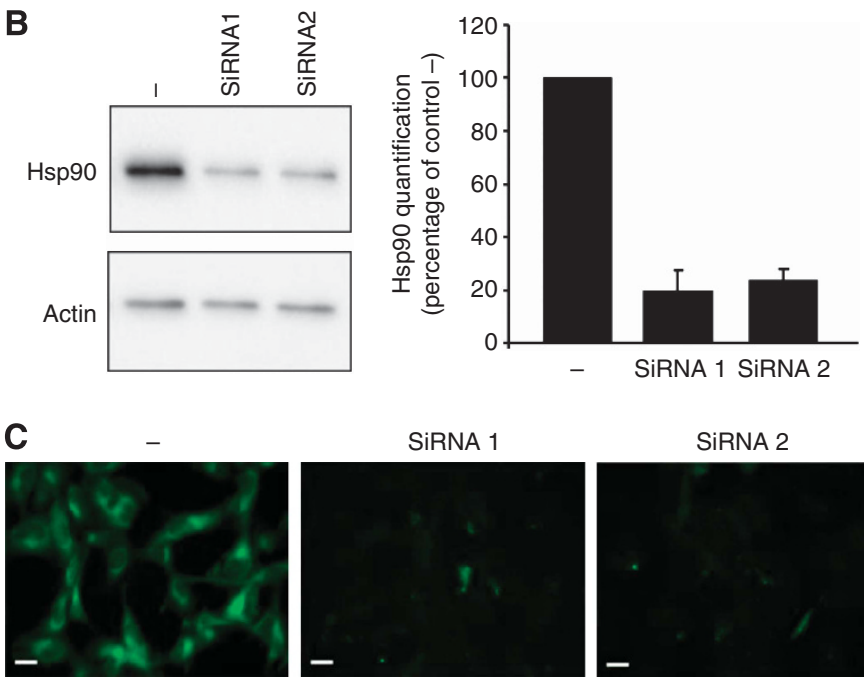

D
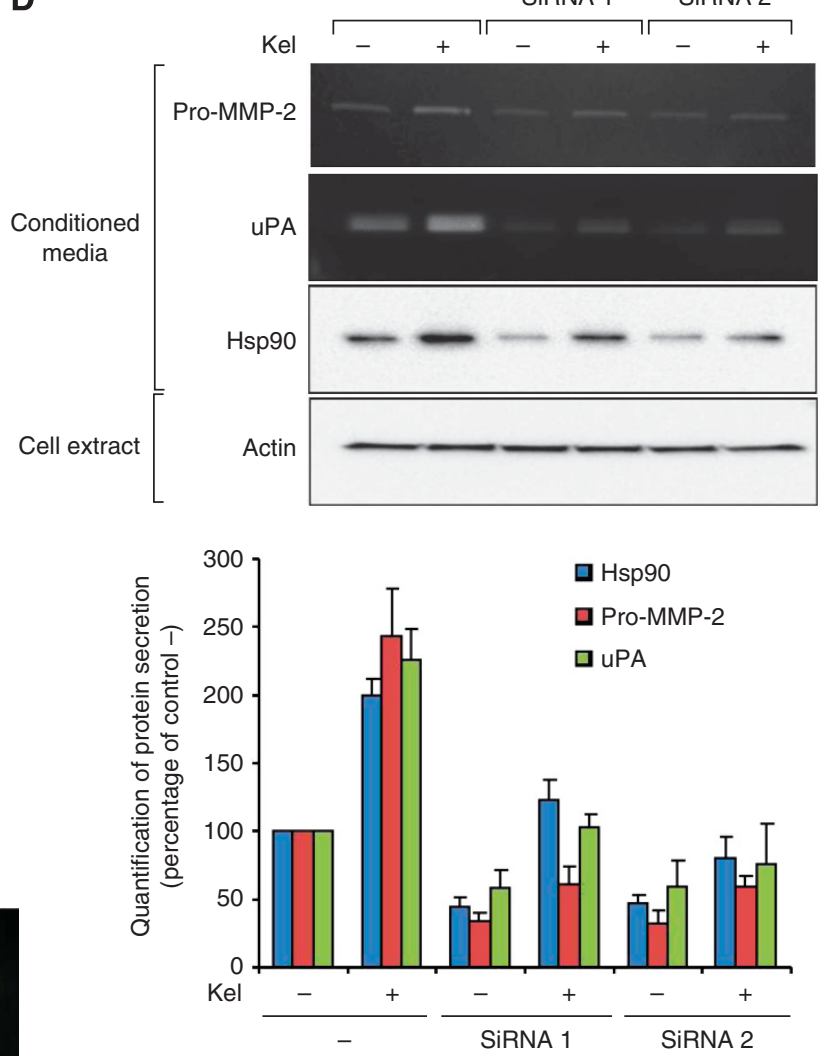

Figure 6. Effect of Hsp90 knockdown on the EDP-regulated pro-MMP-2 and uPA secretion by HT-1080 cells. (A) Real-time PCR analysis of Hsp90 $\alpha$ transcript 2 mRNA relative expression $48 \mathrm{~h}$ after treatment with Hsp90 siRNA vs negative control siRNA-treated cells (-). Results (mean \pm s.e.m.; $n=3$ ) were expressed as the ratio of Hsp90 $\alpha$ transcript 1 mRNA to EEF1a1 mRNA. (B) Western blotting analysis and quantification of intracellular Hsp90 using a rabbit anti-Hsp90 monoclonal antibody and probing with anti-actin $72 \mathrm{~h}$ after treatment with Hsp90 siRNA vs negative control siRNA-treated cells $(-)$ as described in Materials and Methods section. Results (mean \pm s.e.m.) were expressed as the percentage of negative control siRNA-treated cells (EDP-untreated cells). (C) Immunolocalisation of Hsp90 $72 \mathrm{~h}$ after treatment with siRNA to Hsp90 mRNA vs negative control siRNA-treated cells ( - ). Cells were cultured on glass slides, fixed with paraformaldehyde and labelled with an anti-Hsp90 antibody (green). Scale bar: $20 \mu \mathrm{m}$. (D) Gelatin zymography, gelatin plasminogen zymography and western blotting analysis of conditioned media in the presence $\left(+: 50 \mu \mathrm{g} \mathrm{ml}^{-1}\right)$ or in the absence (-) of EDPs $72 \mathrm{~h}$ after treatment with Hsp90 siRNA vs negative control siRNA-treated cells. Quantitative evaluation of protein secretions by HT-1080 cells on gelatin zymography, gelatin plasminogen zymography and by western blotting. Results (mean \pm s.e.m.) were expressed as the percentage of control (negative control siRNA/EDP-untreated cells).

increased in the negative control siRNA cells (pro-MMP-2: $222 \%$; uPA: $225 \%$ ). In the siRNA1- and siRNA2-transfected cells, Kel treatments only slightly increased pro-MMP-2 and uPA secretion. These results confirm that pro-MMP-2 and uPA secretions are independent of Hsp90 expression and that the EDP stimulation of pro-MMP-2 and uPA involves Hsp90.

Hsp90 protect secreted pro-MMP-2 and uPA from degradation. To check pro-MMP-2 and uPA stability in the conditioned media, HT-1080 cells were treated with or without $\mathrm{Kel}\left(50 \mu \mathrm{g} \mathrm{ml}^{-1}\right)$ for $24 \mathrm{~h}$. Collected conditioned media were incubated for 6, 24 and $48 \mathrm{~h}$ at $+37^{\circ} \mathrm{C}$ and analysed by gelatin zymography for proMMP-2 level and gelatin plasminogen zymography for uPA level. Pro-MMP- 2 and uPA contents were decreased by $85 \%$ and $90 \%$, respectively, in the control condition after $48 \mathrm{~h}$ of incubation at $+37{ }^{\circ} \mathrm{C}$ and only by $26 \%$ and $30 \%$, respectively, in the medium collected after Kel treatment. Addition of recombinant Hsp90 in the control conditioned medium $\left(50 \mu \mathrm{g} \mathrm{ml}^{-1}\right)$ prevented proMMP-2 and uPA decrease, as observed in the Kel-treated conditioned medium (Supplementary Figure 3).

\section{DISCUSSION}

In this study, we showed that (a) EDPs increased the secretion of Hsp90; (b) this expression involved a rapid but stable posttranscriptional mechanism; (c) this EDP-dependent Hsp90 release was essential for cancer cell motility and their invasive capacities by increasing extracellular proteases. We first provided evidence that treatment of HT-1080 cells with EDPs increased Hsp90 production; a 4.5-fold increase in $\mathrm{Hsp} 90$ secretion was reached at $50 \mu \mathrm{g} \mathrm{ml}^{-1}$ EDPs, a concentration close to those determined in physiological fluids (Fülöp et al, 1990). This effect could be reproduced by the VGVAPG hexapeptide, thus involving the elastin complex receptor (S-Gal/PPCA/Neu1) in triggering Hsp90 production. We previously showed that the type VIII beta-turn conformation adopted by EDPs with GXXPG sequence was essential for inducing different MMP expression in fibroblasts (Brassart et al, 2001) and HT-1080 cells (Huet et al, 2002). The existence of lactose-insensitive VGVAPG receptor on M27 carcinoma cells does not exclude the involvement of this type of EDP receptor in the Hsp90 secretion (Blood and Zetter, 1993). 
In accordance with the stimulation of cell invasion, we showed that EDPs trigger at the same time the release of Hsp90, MMP-2 and uPA. Immunoprecipitation experiments suggested that these three extracellular proteins and the active form of pro-MMP-2 and MMP-2 were associated. This metzincin protease has largely been shown to be overexpressed in numerous cancers (Chang and Werb, 2001) and its expression by tumour cells themselves or by stromal cells leads to high invasive abilities (Polette et al, 2004). Urokinase plasminogen activator is also involved in tumour invasion by regulating plasminogen activation, leading to ECM degradation and to MMP activation (Sidenius and Blasi, 2003). Increased release of these two proteases by tumour cells could be implicated in the increased invasive capacities of invasive tumour cells treated with EDPs. The EDP-dependent Hsp90 secretion by cancer cells, combined with the protease release, could explain the exacerbation of the cancer cells' invasive power in the presence of EDPs. The crucial role of extracellular Hsp90 on tumour metastasis and tumour angiogenesis has been demonstrated by the fact that rHsp90 promotes angiogenesis in an MMP-2-dependent manner, whereas Hsp90-blocking antibody suppresses it (Eustace et al, 2004; Song et al, 2010; Stellas et al, 2010). These previous studies have shown that extracellular Hsp90 interacts with pro-MMP-2, participating in the activation process and preventing the inactivation of MMP-2. They also showed that only Hsp90 $\alpha$ isoform is present at the cell surface and in the conditioned media of HT-1080 fibrosarcoma cells.

Our studies are significant for several reasons. First, we confirm that extracellular Hsp90 regulates the presence of MMP-2 and demonstrate for the first time that it also regulates the presence of uPA in the pericellular environment. Both proteases interact with the extracellular Hsp90 $\alpha$ and the inhibition of Hsp90 by specific inhibitors, and antibody- or siRNA-mediated gene silencing inhibits the MMP-2 and uPA accumulation in the conditioned media. Second, for the first time, we show that the expression and the secretion of Hsp90 $\alpha$ are controlled by the interaction of EDPs with cell surface receptor. The existence of extracellular Hsp90 $\alpha$ has long been observed and its secretion is considered to use an unconventional way because of the lack of N-terminal signal peptide (Ullrich et al, 1986; Cheng et al, 2008). However, the regulatory mechanism of Hsp90 $\alpha$ secretion is still poorly understood. Some studies relate the fact that Hsp90 $\alpha$ secretion was enhanced under stress conditions, such as hypoxia and oxidative stress (Liao et al, 2000; Clayton et al, 2005; Li et al, 2007). The question then arises of how those different stimuli lead to Hsp $90 \alpha$ secretion.

Among the proteases secreted by cancer cells following EDP treatment, MMP-2 is also an efficient elastase (Senior et al, 1991). In addition to the fact that binding of pro-MMP-2 to elastin modulates its proteolytic activation (Emonard and Hornebeck, 1997), the further fragmentation of elastin matrix owing to the EDP-induced MMP-2 secretion can lead to an increased production of EDPs, resulting in a vicious circle where more EDPs promote more invasion and in turn generating more EDPs. Breaking this exacerbation mechanism by blocking EDP effects with elastin receptor antagonists could be beneficial in these circumstances.

The increased Hsp90 and protease release/accumulation was not related to a transcriptional effect as mRNA encoding Hsp $90 \alpha$, MMP-2 and uPA were not modified. Tumour microvesicles have been linked to Hsp90 secretion (Hegmans et al, 2004), and tumour invasion via release of MMP-2 and uPA (Ginestra et al, 1997; Angelucci et al, 2000; Dolo et al, 2005; Dashevsky et al, 2009). Thus, the lack of transcriptional effect, in combination with the very quick appearance of the effects of EDPs on Hsp90 protein synthesis (15 min of treatment) evokes a post-transcriptional mechanism stimulated by EDPs. A release of Hsp90 and proteases by microvesicles followed by an extracellular Hsp90 stabilisation and activation of proteases may be suggested.
In summary, our study pinpoints, for the first time, EDPs' protumoural key role by inducing Hsp90 secretion, which results in stabilisation and activation of proteases, and finally in tumour dissemination. The EDP-dependent Hsp90 secretion reinforces the fact that initial elastolysis by serine elastases from inflammatory cells or several members of the MMP family in elastin-rich tissues such as the lung, skin and breast must be considered as a main catalytic event in tumour progression.

\section{ACKNOWLEDGEMENTS}

This work was supported by grants from the Centre National de la Recherche Scientifique (UMR 7369), the University of Reims Champagne-Ardenne, the Region Champagne-Ardenne, the Délégation régionale à la Recherche et à la Technologie and the Ligue Nationale contre le Cancer. We thank Dr Christine Terryn (Plateforme IBiSA 'Imagerie Cellulaire et Tissulaire') and Dr Marie-Pierre Courageot for their skilful technical assistance.

\section{CONFLICT OF INTEREST}

The authors declare no conflict of interest.

\section{REFERENCES}

Angelucci A, D’Ascenzo S, Festuccia C, Gravina GL, Bologna M, Dolo V, Pavan A (2000) Vesicle-associated urokinase plasminogen activator promotes invasion in prostate cancer cell lines. Clin Exp Metast 18: $163-170$.

Bax DV, Rodgers UR, Bilek MMM, Weiss AS (2009) Cell adhesion to tropoelastin is mediated via the C-terminal GRKRK motif and integrin alphaVbeta3. J Biol Chem 284: 28616-28623.

Blood CH, Zetter BR (1993) Laminin regulates a tumor cell chemotaxis receptor through the laminin-binding integrin subunit alpha 6. Cancer Res 53: 2661-2666.

Brassart B, Fuchs P, Huet E, Alix AJ, Wallach J, Tamburro AM, Delacoux F, Haye B, Emonard H, Hornebeck W, Debelle L (2001) Conformational dependence of collagenase (matrix metalloproteinase-1) up-regulation by elastin peptides in cultured fibroblasts. J Biol Chem 276: 5222-5227.

Brassart B, Randoux A, Hornebeck W, Emonard H (1998) Regulation of matrix metalloproteinase-2 (gelatinase A, MMP-2), membrane-type matrix metalloproteinase-1 (MT1-MMP) and tissue inhibitor of metalloproteinases-2 (TIMP-2) expression by elastin-derived peptides in human HT-1080 fibrosarcoma cell line. Clin Exp Metast 16: 489-500.

Chang C, Werb Z (2001) The many faces of metalloproteases: cell growth, invasion, angiogenesis and metastasis. Trends Cell Biol 11: S37-S43.

Chen B, Piel WH, Gui L, Bruford E, Monteiro A (2005) The HSP90 family of genes in the human genome: insights into their divergence and evolution. Genomics 86: 627-637.

Cheng CF, Fan J, Fedesco M, Guan S, Li Y, Bandyopadhyay B, Bright AM, Yerushalmi D, Liang M, Chen M, Han YP, Woodley DT, Li W (2008) Transforming growth factor $\alpha$ (TGF $\alpha)$-stimulated secretion of HSP90 $\alpha$ : using the receptor LRP-1/CD91 to promote human skin cell migration against a TGF $\beta$-rich environment during wound healing. Mol Cell Biol 28: 3344-3358.

Clayton A, Turkes A, Mason MD, Tabi Z (2005) Induction of heat shock proteins in B-cell exosomes. J Cell Sci 118: 3631-3638.

Dashevsky O, Varon D, Brill A (2009) Platelet-derived microparticles promote invasiveness of prostate cancer cells via upregulation of MMP-2 production. Int J Cancer 124: 1773-1777.

Dolo V, D’Ascenzo S, Giusti I, Millimaggi D, Taraboletti G, Pavan A (2005) Shedding of membrane vesicles by tumor and endothelial cells. Ital J Anat Embryol 110: 127-133.

Emonard H, Hornebeck W (1997) Binding of $92 \mathrm{kDa}$ and $72 \mathrm{kDa}$ progelatinases to insoluble elastin modulates their proteolytic activation. Biol Chem 378: 265-271. 
Eustace BK, Sakurai T, Stewart JK, Yimlamai D, Unger C, Zehetmeier C, Lain B, Torella C, Henning SW, Beste G, Scroggins BT, Neckers L, Ilag LL, Jay DG (2004) Functional proteomic screens reveal an essential extracellular role for hsp90 alpha in cancer cell invasiveness. Nat Cell Biol 6: 507-514.

Fülöp T, Wei SM, Robert L, Jacob MP (1990) Determination of elastin peptides in normal and arteriosclerotic human sera by ELISA. Clin Physiol Biochem 8: 273-282.

Ginestra A, Monea S, Seghezzi G, Dolo V, Nagase H, Mignatti P, Vittorelli ML (1997) Urokinase plasminogen activator and gelatinases are associated with membrane vesicles shed by human HT1080 fibrosarcoma cells. J Biol Chem 272: 17216-17222.

Grant DS, Tashiro K, Segui-Real B, Yamada Y, Martin GR, Kleinman HK (1989) Two different laminin domains mediate the differentiation of human endothelial cells into capillary-like structures in vitro. Cell $\mathbf{5 8}$ : 933-943.

Grenert JP, Johnson BD, Toft DO (1999) The importance of ATP binding and hydrolysis by hsp 90 in formation and function of protein heterocomplexes. J Biol Chem 274: 17525-17533.

Hance KA, Tataria M, Ziporin SJ, Lee JK, Thompson RW (2002) Monocyte chemotactic activity in human abdominal aortic aneurysms: role of elastin degradation peptides and the $67-\mathrm{kD}$ cell surface elastin receptor. $J$ Vasc Surg 35: 254-261.

Hegmans JPJJ, Bard MPL, Hemmes A, Luider TM, Kleijmeer MJ, Prins JB, Zitvogel L, Burgers SA, Hoogsteden HC, Lambrecht BN (2004) Proteomic analysis of exosomes secreted by human mesothelioma cells. Am J Pathol 164: $1807-1815$.

Hinek A, Boyle J, Rabinovitch M (1992) Vascular smooth muscle cell detachment from elastin and migration through elastic laminae is promoted by chondroitin sulfate-induced 'shedding' of the $67-\mathrm{kDa}$ cell surface elastin binding protein. Exp Cell Res 203: 344-353.

Huet E, Brassart B, Cauchard JH, Debelle L, Birembaut P, Wallach J, Emonard H, Polette M, Hornebeck W (2002) Cumulative influence of elastin peptides and plasminogen on matrix metalloproteinase activation and type I collagen invasion by HT-1080 fibrosarcoma cells. Clin Exp Metast 19: 107-117.

Huet E, Brassart B, Wallach J, Debelle L, Haye B, Emonard H, Hornebeck W (2001) Effect of elastin peptides on the production of matrix metalloproteinase 2 by human skin fibroblasts in culture. J Soc Biol 195: 165-172.

Jacob M, Hornebeck W (1985) Isolation and characterization of insoluble and kappa-elastins. Front Matrix Biol 10: 92-129.

Kamoun A, Landeau JM, Godeau G, Wallach J, Duchesnay A, Pellat B, Hornebeck W (1995) Growth stimulation of human skin fibroblasts by elastin-derived peptides. Cell Adhes Commun 3: 273-281.

Li W, Li Y, Guan S, Fan J, Cheng CF, Bright AM, Chinn C, Chen M, Woodley DT (2007) Extracellular heat shock protein-90alpha: linking hypoxia to skin cell motility and wound healing. Eur Mol Biol Organ J 26: 1221-1233.

Liao DF, Jin ZG, Baas AS, Daum G, Gygi SP, Aebersold R, Berk BC (2000) Purification and identification of secreted oxidative stress-induced factors from vascular smooth muscle cells. J Biol Chem 275: 189-196.

Maeda I, Mizoiri N, Briones MPP, Okamoto K (2007) Induction of macrophage migration through lactose-insensitive receptor by elastin-derived nonapeptides and their analog. J Pept Sci 13: 263-268.

Nackman GB, Karkowski FJ, Halpern VJ, Gaetz HP, Tilson MD (1997) Elastin degradation products induce adventitial angiogenesis in the Anidjar/ Dobrin rat aneurysm model. Surgery 122: 39-44.

Ntayi C, Labrousse AL, Debret R, Birembaut P, Bellon G, Antonicelli F, Hornebeck W, Bernard P (2004) Elastin-derived peptides upregulate matrix metalloproteinase-2-mediated melanoma cell invasion through elastin-binding protein. J Invest Dermatol 122: 256-265.

Polette M, Nawrocki-Raby B, Gilles C, Clavel C, Birembaut P (2004) Tumour invasion and matrix metalloproteinases. Crit Rev Oncol 49: 179-186.
Robert L (1996) Aging of the vascular wall and atherogenesis: role of the elastin-laminin receptor. Atherosclerosis 123: 169-179.

Robinet A, Fahem A, Cauchard JH, Huet E, Vincent L, Lorimier S, Antonicelli F, Soria C, Crepin M, Hornebeck W, Bellon G (2005) Elastin-derived peptides enhance angiogenesis by promoting endothelial cell migration and tubulogenesis through upregulation of MT1-MMP. J Cell Sci 118: 343-356.

Rucker RB, Dubick MA (1984) Elastin metabolism and chemistry: potential roles in lung development and structure. Environ Health Perspect 55: $179-191$.

Samouillan V, Lamure A, Maurel E, Lacabanne C, Hornebeck W (2001) Alterations in the chain dynamics of insoluble elastin upon proteolysis by serine elastases. Biopolymers 58: 175-185.

Senior RM, Griffin GL, Fliszar CJ, Shapiro SD, Goldberg GI, Welgus HG (1991) Human 92- and 72-kilodalton type IV collagenases are elastases. J Biol Chem 266: 7870-7875.

Senior RM, Griffin GL, Mecham RP (1980) Chemotactic activity of elastin-derived peptides. J Clin Invest 66: 859-862.

Sidenius N, Blasi F (2003) The urokinase plasminogen activator system in cancer: recent advances and implication for prognosis and therapy. Cancer Metast Rev 22: 205-222.

Sims JD, McCready J, Jay DG (2011) Extracellular heat shock protein (Hsp)70 and Hsp90 $\alpha$ assist in matrix metalloproteinase-2 activation and breast cancer cell migration and invasion. PLoS One 6: 12.

Song X, Wang X, Zhuo W, Shi H, Feng D, Sun Y, Liang Y, Fu Y, Zhou D, Luo Y (2010) The regulatory mechanism of extracellular Hsp90alpha on matrix metalloproteinase- 2 processing and tumor angiogenesis. J Biol Chem 285: 40039-40049.

Starkey JR (1990) Cell-matrix interactions during tumor invasion. Cancer Metast Rev 9: 113-123.

Stellas D, El Hamidieh A, Patsavoudi E (2010) Monoclonal antibody 4C5 prevents activation of MMP2 and MMP9 by disrupting their interaction with extracellular HSP90 and inhibits formation of metastatic breast cancer cell deposits. BMC Cell Biol 11: 51.

Timar J, Lapis K, Fulop T, Varga ZS, Tixier JM, Robert L, Hornebeck W (1991) Interaction between elastin and tumor cell lines with different metastatic potential; in vitro and in vivo studies. J Cancer Res Clin Oncol 117: 232-238.

Toupance S, Brassart B, Rabenoelina F, Ghoneim C, Vallar L, Polette M, Debelle L, Birembaut P (2012) Elastin-derived peptides increase invasive capacities of lung cancer cells by post-transcriptional regulation of MMP-2 and uPA. Clin Exp Metast 29: 511-522.

Tsutsumi S, Neckers L (2007) Extracellular heat shock protein 90: a role for a molecular chaperone in cell motility and cancer metastasis. Cancer Sci $\mathbf{9 8}$ : 1536-1539.

Ullrich SJ, Robinson EA, Appella E (1986) Characterization of a chemically homogeneous tumor antigen from a methylcholanthrene-induced sarcoma. Method A 23: 545-555.

Visse R, Nagase H (2003) Matrix metalloproteinases and tissue inhibitors of metalloproteinases: structure, function, and biochemistry. Circ Res 92: $827-839$.

Wang X, Song X, Zhuo W, Fu Y, Shi H, Liang Y, Tong M, Chang G, Luo Y (2009) The regulatory mechanism of Hsp90alpha secretion and its function in tumor malignancy. Proc Natl Acad Sci USA 106: 21288-21293.

Werb Z, Banda MJ, McKerrow JH, Sandhaus RA (1982) Elastases and elastin degradation. J Invest Dermatol 79: 154s-159s.

This work is published under the standard license to publish agreement. After 12 months the work will become freely available and the license terms will switch to a Creative Commons AttributionNonCommercial-Share Alike 3.0 Unported License.

Supplementary Information accompanies this paper on British Journal of Cancer website (http://www.nature.com/bjc) 